\title{
Determinant Factors of Young People in Preparing for Entrepreneurship: Lesson from Indonesia*
}

\author{
Ludi Wishnu WARDANA ${ }^{1}$, Puji HANDAYATI ${ }^{2}$, Bagus Shandy NARMADITYA ${ }^{3}$, Agus WIBOWO ${ }^{4}$, \\ Tudung Subali PATMA ${ }^{5}$, Sandy Eka SUPRAJAN ${ }^{6}$
}

Received: June 02, 2020 Revised: June 14, 2020 Accepted: July 09, 2020

\begin{abstract}
This study examines the determinant factors affecting young people in preparing entrepreneurship in Indonesia. This study involved several variables, including the need for achievement, risk perception, locus of control, entrepreneurial attitude to predict entrepreneurial intention, and preparation for entrepreneurship among young people. The approach utilized in this study was a quantitative research design using a survey model. The participants of this study were recruited from young people in East Java, Indonesia. Structural equation modeling with Partial Least Square (SEM-PLS) was implemented to test the hypotheses and the relationships between variables. The findings of this research showed that the attitudes toward entrepreneurship and entrepreneurial intention of young people in Indonesia are determined by several variables such as the need for achievement, risk perception, and locus of control. The correlation between variables showed one positive direction in which all independent variables can influence dependent variables. Additionally, the result of this study confirms a robust relationship between the attitude toward entrepreneurship and preparing for entrepreneurship among young people. Lastly, this study showed a positive correlation between entrepreneurial intention and preparation for entrepreneurship. This study suggests that government institutions and universities need to be concerned about entrepreneurial programs to promote young entrepreneurs.
\end{abstract}

Keywords: Need for Achievement, Risk Perception, Locus of Control, Entrepreneurship, Entrepreneurial Intentions

JEL Classification Code: D91, J13, L26

\section{Introduction}

Entrepreneurship plays a pivotal role in facilitating the enhancement of a country (Hsiao et al., 2015; Yi et al., 2018).

\footnotetext{
*Acknowledgements:

We are grateful to anonymous reviewers and editor of the journal for their valuable comments and suggestions an effort to improve the quality of article.

${ }^{1}$ First Author and Corresponding Author. Faculty of Economics, Universitas Negeri Malang, Indonesia [Postal Address: Jalan Semarang 5 Malang, 65145, Indonesia]

Email: ludi.wishnu.fe@um.ac.id

${ }^{2}$ Faculty of Economics, Universitas Negeri Malang, Indonesia ${ }^{3}$ Faculty of Economics, Universitas Negeri Malang, Indonesia ${ }^{4}$ Faculty of Economics, Universitas Negeri Jakarta, Indonesia ${ }^{5}$ Teknik Elektronika, Politeknik Negeri Malang, Indonesia

${ }^{6}$ Program Studi Manajemen, STIE Kesuma Negara Blitar, Indonesia

(c) Copyright: The Author(s)

This is an Open Access article distributed under the terms of the Creative Commons Attribution Non-Commercial License (http://Creativecommons.org/licenses/by-nc/4.0/) which permits unrestricted noncommercial use, distribution, and reproduction in any medium, provided the original work is properly cited.
}

Additionally, entrepreneurship also acts as a generator in providing national welfare and competitiveness through better job opportunities (Ma \& Tan, 2006). The crucial role of entrepreneurship has gained attention among policymakers and scholars throughout the world. In fact, there has been no structured attempt to investigate entrepreneurship from the point of view of young people (Chant \& Jones, 2005). As a consequence, the insufficient understanding of youth studies leads to the narrow potential to touch young people (Dejaeghere, 2014).

The primary objective of this study aims to promote the potential advantages of youth entrepreneurs as a viable career choice, to examine challenges that stand in the way, and policy steps and strategies (Connor, 2013; Lordkipanidze et al., 2005). There is generally no accurate and systematic data about young people, especially data relating to youth entrepreneurship (Hill, 2006). Therefore, this research is based on various sources that form the basis of analysis. The existing evidence in developing countries showed that the level of entrepreneurship is linked to youth community in the welfare nations (Iakovleva \& Kolvereid, 2011). 
In the context of Indonesia, the number of entrepreneurs has experienced an upward trend. It was about 1.67 percent in 2018 and rose to almost double to the level of 3.10 percent in 2019 , with a total of 400,000 entrepreneurs. However, this achievement is still far from the expected number, ideally two million entrepreneurs. Also, educational approaches and other competencies to prepare successful entrepreneurs are problems that must be addressed (Statistics Indonesia, 2019). Therefore, Indonesia needs an educated young generation to continue the government relay and the struggle of this nation. The number of employment opportunities is limited and is no longer able to compensate for the rate of population growth in Indonesia, especially at a productive age (Suparno et al., 2019).

Some literature on entrepreneurship points out that the presence of entrepreneurs in society is determined by consumer demand and can be learned through training and experience (Priem \& Carr, 2012; Luc, 2018). Also, several studies found that the emergence of entrepreneurship in a society is determined by the values or culture adopted by the community, and psychologists find that the emergence of entrepreneurship is determined by the characteristics of each individual (Wagner \& Sternberg, 2004).

The individual characteristics of each person are related to the core values and character of a young entrepreneur (Rode $\&$ Vallaster, 2005). Indeed, Hunter et al. (2003) remarked that many perspectives try to explain the entrepreneurial process as follows. First, the scholars are concerned with the individual personality characteristics, such as risktaking and the values of innovation and work. The second research group has taken a social cognitive approach, seeking out the correlation between individuals and their circumstances. The relationship between entrepreneurs, personality characteristics, values, and other dimensions will help determine why some people become entrepreneurs (Markman \& Baron, 2003).

Various studies have reported that there are still some weaknesses in the successful young entrepreneurs in Indonesia. It is relevant to have a blueprint for how to prepare the next young entrepreneur to provide understanding and education about the importance of recognizing core characters and values for a young entrepreneur (Baion \& Marfcman, 2000; Nelles, 2011). It is expected that they can prepare themselves to become successful young entrepreneurs (Nga \& Shamuganathan, 2010). Based on the previous findings, this study attempts to understand what factors affect young people to become entrepreneurs focusing on the need for achievement, risk perception, locus of control, entrepreneurial attitudes, and entrepreneurial intentions.

\section{Literature Review}

\subsection{Need for Achievement}

The need for achievement has been examined comprehensively by McClelland (1961). Schaper and Weber (2011) state that the need for achievement is a condition in someone who wishes to be superior or to succeed in competitive situations. A prior study by Tong et al. (2011) remarked this variable plays an essential role in forecasting entrepreneurial intentions and individuals with high demand for achievement in providing more entrepreneurial activity. Likewise, Ferreira et al. (2012) and Nasip et al. (2017) mentioned that the need for achievement can trigger the intention to become entrepreneurs. In addition, there is some consensus suggesting that the need for achievement also has a close relationship with an entrepreneurial attitude and entrepreneurial intentions (Botsaris \& Vamvaka, 2016; Dakoumi \& Abdelwahed, 2014; Jena, 2020).

H1: The need for achievement has a positive impact on the entrepreneurial attitude

H2: The need for achievement has a positive impact on the entrepreneurial intention

\subsection{Risk Perception}

The concept of entrepreneurial risk perception covers the assessment of risk decision-making, which affects entrepreneurial behaviors (Nabi \& Liñán, 2013). This includes individual assessments and estimated probabilities of levels and risk control, for instance, in preparing for entrepreneurship and trust in those forecasts (Barbosa \& Fayolle, 2006; Mullins \& Forlani, 2005). Experts have stated that businessman do not always have a higher risk tendency (Simon et al., 2000). In contrast, empirical research shows differences in the risk perception hypothesis, where entrepreneurs are more likely to consider bringing down levels of risk associated with the creation of new ventures (Barbosa \& Fayolle, 2006). This happens by using rose-colored lenses, that is, exaggerating their opportunities of success and positively framing business creation (Douglas, 2017). Thus, these potential entrepreneurs focus on the positive dimension by looking at strengths and opportunities instead of weaknesses and threats. This risk perception predicts individual entrepreneurial intentions (Barbosa \& Fayolle, 2006) and the creation of new ventures (Simon et al., 2000). It, thus, is considered an essential factor in understanding entrepreneurial cognition and behavior. 


\section{H3: Risk perception positively influences entrepreneurial attitude \\ H4: Risk perception positively influences entrepreneurial intention}

\subsection{Locus of Control}

Locus of control means an individual's perception of rewards and punishment in one's life (Helson, 1980). This can be called the level of control a person has over events in their life (Rotter, 1966). Individuals with an internal locus of control have a strong belief that they control events in their own lives. In contrast, individuals with an external locus of control refer to events on extrinsic factors, including fates, opportunities, or luck. This implies that intrinsic locus of control is one of the main characteristics of entrepreneurship and can be a significant factor of company success and failure (Fock \& Koh, 2006; Cromie et al., 2000). Locus of control refers to the perception that a person can influence certain accomplishments that are relevant to them. People with an internal locus of control believe results are the result of their efforts, will, and abilities. The construct of locus of control has been widely used in extant research as a predictor of behavior ranging from the centrality of work and alienation to work frustration and aggression (Fox \& Spector, 1999), to entrepreneurial potential and moral reasoning. (Mueller \& Thomas, 2001). However, in the case of attitude towards money, except for Tang (1995), several studies try to examine the effect that the locus of control has on the meaning that people associate with money. In addition, a person with an external locus of control tends to believe that the results are beyond their control and extrinsic variables such as environment, lucks, getting to know the right people and so forth. Additionally, Bonnett (1991) found that internal locus of control was closely related to the willingness to be an entrepreneur.

H5: The locus of control has a positive impact on the entrepreneurial attitude

H6: The locus of control has a positive impact on the entrepreneurial intention

\subsection{Attitude toward Entrepreneurship and Entrepreneurial Intention}

In early attitude research, most scholars accept that a given attitude regulates behavior. When critics began to question this, it suddenly seemed that attitude was a predictor of terrible behavior. The validity of this study was based on the question of whether socially-desirable biases contaminated respondents or that measurement provides an incomplete assessment of the construct of attitude. Ajzen and Fishbein (1997) criticize research that often tries to predict concrete actions by measuring very global attitudes and therefore fails to find a clear relationship between attitudes and behavior.

Attitudes are generally vital because they affect perception and behavior. However, people who have the same attitude may still act differently in certain situations (Ajzen, 2002; Schifter \& Ajzen, 1985). These differences can be ascribed to, for example, accessibility, strength, and the importance of direct attitudes and experiences (Fazio \& Williams, 2015). For example, most companies have positive attitudes towards ethical behavior, but not all of these companies act ethically. Whether they act ethically or not depends on how strongly they care about this problem. Schifter and Ajzen (1985) show that we must distinguish between two different types of attitudes. The general attitude is useful when predicting behavior patterns or several criteria of action, but weak in terms of predicting a single behavior. Attitude towards a behavior is a stronger predictor than a single behavior.

Preparing for entrepreneurship requires attitudes towards entrepreneurship (Liñán et al., 2011). Transforming the significant role of entrepreneurship impact in the nation development and economic growth will force the country to boost the number of young entrepreneurs. Likewise, for Filion (2015), is included in the category of "entrepreneurial foundations", a series of training, which can be clearly considered as entrepreneurship education. Specifically, in addition to emphasizing the importance of attitudes towards entrepreneurship in preparing for entrepreneurship, the following content can be highlighted: transmitting entrepreneurial roles and aspects, along with problems that are usually encountered; providing clarification that they can be encouraged and presenting several techniques for doing so, and making explicit successive stages engaged in the initial process and business enhancement (Borasi \& Finnigan, 2010; Schwartz \& Malach-Pines, 2009).

H7: Entrepreneurial attitude positively influences
entrepreneurial intention
H8: Entrepreneurial attitude positively influences
preparing for entrepreneurship
H9: Entrepreneurial intention positively influences
preparing for entrepreneurship

\section{Research Methods}

\subsection{Study Design}

This study applied a cross-sectional survey with participant entrepreneurs in East Java, Indonesia. A total of 425 questionnaires were distributed online. However, approximately 404 responses were applicable for further analysis. The responses rate of $95 \%$ is relatively high. 
In more detail, the $74 \%$ respondents of this study were female with the age between 18 to 25 years old and having working experience for about 1 to 5 years. Most respondents graduated from senior high school, with the percentage of $57 \%$ and running their business in home industry and coffee shop, with $74 \%$ and $17 \%$, respectively (see Figure 1).

\subsection{Measurement Development}

All the construct's measurements were adapted from previous studies with a minor modification. The questionnaire included 35 questions framing the respondent's profile and variables, which were investigated. Attitudes toward entrepreneurship (ATE) were proxied by four questions based on Linan and Chen (2009). Entrepreneurial intentions (EI) were estimated by using six indicators adapted from Linan and Chen (2009). Locus of control (LC) was explained by four indicators borrowed from Rotter (1966). The need for achievement (NAC) was measured by four items based on Cassidy and Lynn (1989). Preparing for Entrepreneurship (PR) was measured by seven items adapted from Tung et al. (2020), and risk perception (RI) was measured by five items based on Gomez-Mejia and Balkin (1989). Each construct was measured on the 5-point Likert scale, from "strongly disagree" (1) to "strongly agree" (5).

\section{Results}

\subsection{Assessment of Outer Model}

The first step of outer model assessment in PLS analysis is an examination to ensure that the instrument is reliable. The score between $0.6-0.8$ indicates good construct reliability
(Hair et al., 2014). For validity analysis, construct validity is applied since it is more relevant for the social sciences (Cronbach, 1995). Two sorts of validity tests were performed, convergent validity and discriminant validity. Convergent validity is the extent to which a measure positively correlates with another measure of the same construct. In examining the convergent validity of a measure in PLS, the average variance extracted (AVE) and item loadings are evaluated (Hair et al., 2013). A AVE value higher than 0.50 indicates that, on average, the construct explained more than half of its indicator variance. As such, the rule of thumb is that an AVE value greater or equal to 0.50 is acceptable (Hair et al., 2013).

As shown in Table 1, the values of CR for each construct range from 0.835-0.906 exceed 0.6-0.7 as a cut-off score, so the construct reliability is achieved. The convergence validity test results in some of the indicators (EI3, EI6, ATE4, LC2, LC4, PR1, PR3, PR4, PR5, PR7, NAC2, NAC3, RI1, RI2, and RI3) should be removed due to the items loading lower than 0.7. After the elimination, all the items are loading higher than 0.6 and the value of AVE for each construct ranges from 0.644-0.760 exceed the recommended value 0.5 , thus the convergence validity is achieved.

Table 2 shows the discriminant validity test in which items differentiate among constructs or measure distinct concepts. The AVE for each component should be greater than the squares of the correlation between the components and all other components (Fitch et al., 2005). On the other hand, the research model is considered to have a good discriminant when the correlation among the components is lower than the square root of the AVE (Fornell \& Larcker, 1981).

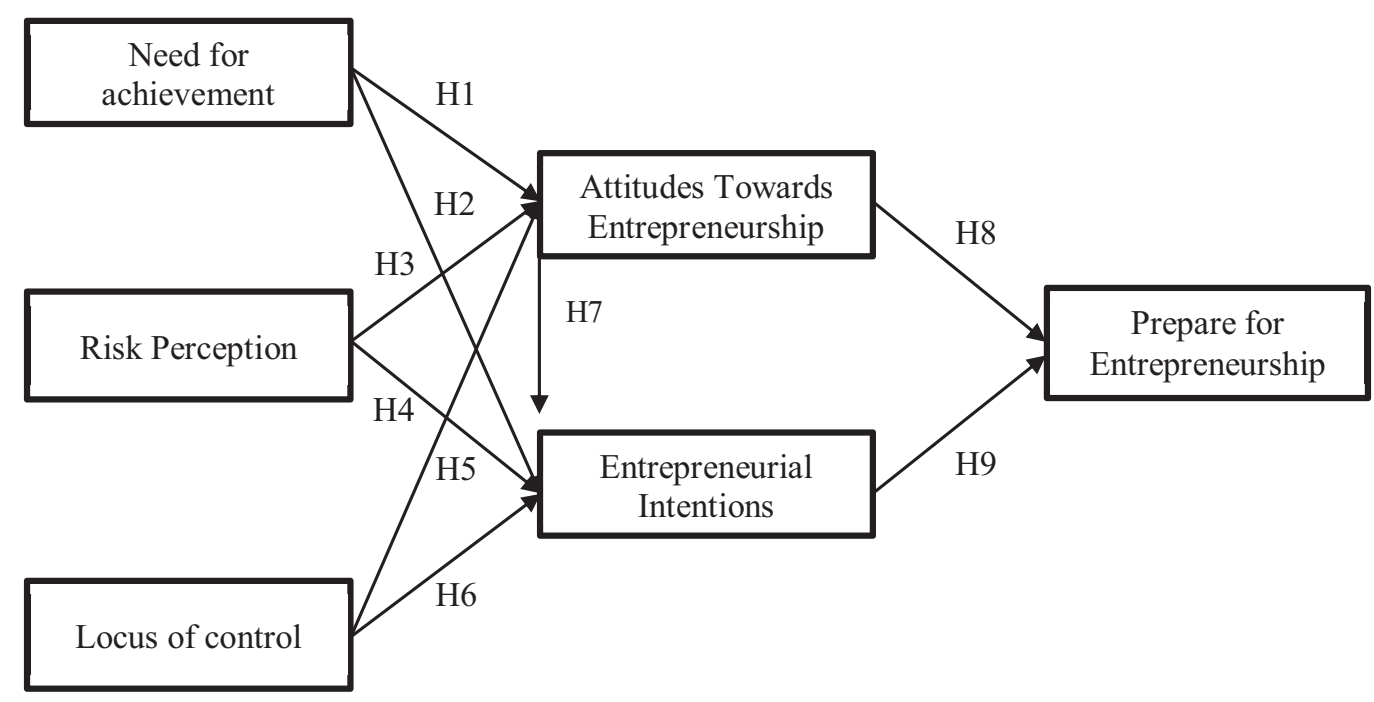

Figure 1: The research framework 
Table 1: Results of Measurement (Outer) Model

\begin{tabular}{|c|c|c|c|c|c|}
\hline Construct & Item & Loading & CR & Cronbach Alpha & AVE \\
\hline \multirow{4}{*}{$\begin{array}{l}\text { Attitudes towards entrepreneurship } \\
\text { (ATE) }\end{array}$} & ATE1 & 0.867 & \multirow{4}{*}{0.906} & \multirow{4}{*}{0.862} & \multirow{4}{*}{0.707} \\
\hline & ATE2 & 0.831 & & & \\
\hline & ATE3 & 0.848 & & & \\
\hline & ATE5 & 0.816 & & & \\
\hline \multirow[t]{4}{*}{ Entrepreneurial intentions (EI) } & El1 & 0.794 & \multirow{4}{*}{0.878} & \multirow{4}{*}{0.816} & \multirow{4}{*}{0.644} \\
\hline & El2 & 0.811 & & & \\
\hline & El4 & 0.816 & & & \\
\hline & EI5 & 0.788 & & & \\
\hline \multirow[t]{2}{*}{ Locus of control (LC) } & LC1 & 0.905 & \multirow{2}{*}{0.863} & \multirow{2}{*}{0.688} & \multirow{2}{*}{0.760} \\
\hline & LC3 & 0.837 & & & \\
\hline \multirow[t]{2}{*}{ Need for achievement (NAC) } & NAC1 & 0.864 & \multirow[t]{2}{*}{0.849} & \multirow[t]{2}{*}{0.645} & \multirow[t]{2}{*}{0.738} \\
\hline & NAC4 & 0.854 & & & \\
\hline \multirow{2}{*}{$\begin{array}{l}\text { Prepare for Entrepreneurship } \\
\text { (PR) }\end{array}$} & PR2 & 0.885 & \multirow[t]{2}{*}{0.839} & \multirow[t]{2}{*}{0.622} & \multirow[t]{2}{*}{0.723} \\
\hline & PR6 & 0.814 & & & \\
\hline \multirow[t]{2}{*}{ Risk Perception (RI) } & RI4 & 0.906 & \multirow[t]{2}{*}{0.835} & \multirow[t]{2}{*}{0.619} & \multirow[t]{2}{*}{0.718} \\
\hline & RI5 & 0.784 & & & \\
\hline
\end{tabular}

Table 2: Discriminant Validity

\begin{tabular}{|l|c|c|c|c|c|c|}
\hline & ATE & EI & LC & NAC & PR & RI \\
\hline Attitudes towards entrepreneurship (ATE) & 0.841 & & & & & \\
\hline Entrepreneurial intentions (EI) & 0.790 & 0.802 & & & & \\
\hline Locus of control (LC) & 0.557 & 0.587 & 0.872 & & & \\
\hline Need for achievement (NAC) & 0.624 & 0.616 & 0.574 & 0.859 & & \\
\hline Prepare for Entrepreneurship (PR) & 0.487 & 0.541 & 0.479 & 0.496 & 0.851 & \\
\hline Risk Perception (RI) & 0.572 & 0.620 & 0.498 & 0.526 & 0.449 & 0.847 \\
\hline
\end{tabular}

\subsection{Assessment of Structural (Inner) Model}

All the data were run using 500 bootstrapped samples, through 130 cases. Variance Inflation Factor (VIF) coefficient is higher than 5.00 (Hair et al., 2014). The test results showed that the range of inner VIF is within $1.251-$ 2.334. Therefore, there is no collinearity problem.

\subsection{Path Coefficient}

The path coefficients are also used to evaluate the structural (inner) models. The t-statistics were estimated using the bootstrap resampling procedure. The bootstrapping procedure is a non-parametric approach for estimating the precision of the PLS-SEM estimates (Hair et al., 2013). Bootstrapping results suggest the stability of the PLS-
SEM estimates. In this study, all the data was run using 500 bootstrapped samples. As shown in Table 3, all of the hypotheses were accepted since the range of $p$-value for each relationship is within $0.000-0.033$, less than 0.05 (see Figure 2).

\subsection{Model Fit}

The model R-square indicates the model's predictive accuracy (Hair et al., 2014). R-square values falling on or greater than 0.75 are considered as substantial, those that fall on 0.50 are considered moderate, and those that are 0.25 are considered as weak (Hair et al., 2014). The results show that $50 \%$ variance of ATE was explained by NAC, RI and LC, which is a moderate level of predictivity. Furthermore, $68.7 \%$ variance of EI was explained by ATE, NAC, RI, 
Table 3: Path Coefficients and Results of Hypotheses Testing

\begin{tabular}{|c|c|c|c|c|c|}
\hline Hypotheses & Relationship & Beta & T-value & P-values & Decision \\
\hline $\mathrm{H}_{1}$ & $\mathrm{NAC} \rightarrow \mathrm{ATE}$ & 0.354 & 6.529 & 0.000 & Accepted \\
\hline $\mathrm{H}_{2}$ & $\mathrm{NAC} \rightarrow \mathrm{EI}$ & 0.101 & 2.589 & 0.010 & Accepted \\
\hline $\mathrm{H}_{3}$ & $\mathrm{RI} \rightarrow \mathrm{ATE}$ & 0.279 & 6.373 & 0.000 & Accepted \\
\hline $\mathrm{H}_{4}$ & $\mathrm{RI} \rightarrow \mathrm{EI}$ & 0.189 & 4.507 & 0.000 & Accepted \\
\hline $\mathrm{H}_{5}$ & $\mathrm{LC} \rightarrow \mathrm{ATE}$ & 0.215 & 4.483 & 0.000 & Accepted \\
\hline $\mathrm{H}_{6}$ & $\mathrm{LC} \rightarrow \mathrm{EI}$ & 0.132 & 3.521 & 0.000 & Accepted \\
\hline $\mathrm{H}_{7}$ & $\mathrm{ATE} \rightarrow \mathrm{El}$ & 0.545 & 13.276 & 0.000 & Accepted \\
\hline $\mathrm{H}_{8}$ & $\mathrm{ATE} \rightarrow \mathrm{PR}$ & 0.160 & 2.144 & 0.033 & Accepted \\
\hline $\mathrm{H}_{9}$ & $\mathrm{EI} \rightarrow \mathrm{PR}$ & 0.414 & 5.321 & 0.000 & Accepted \\
\hline
\end{tabular}

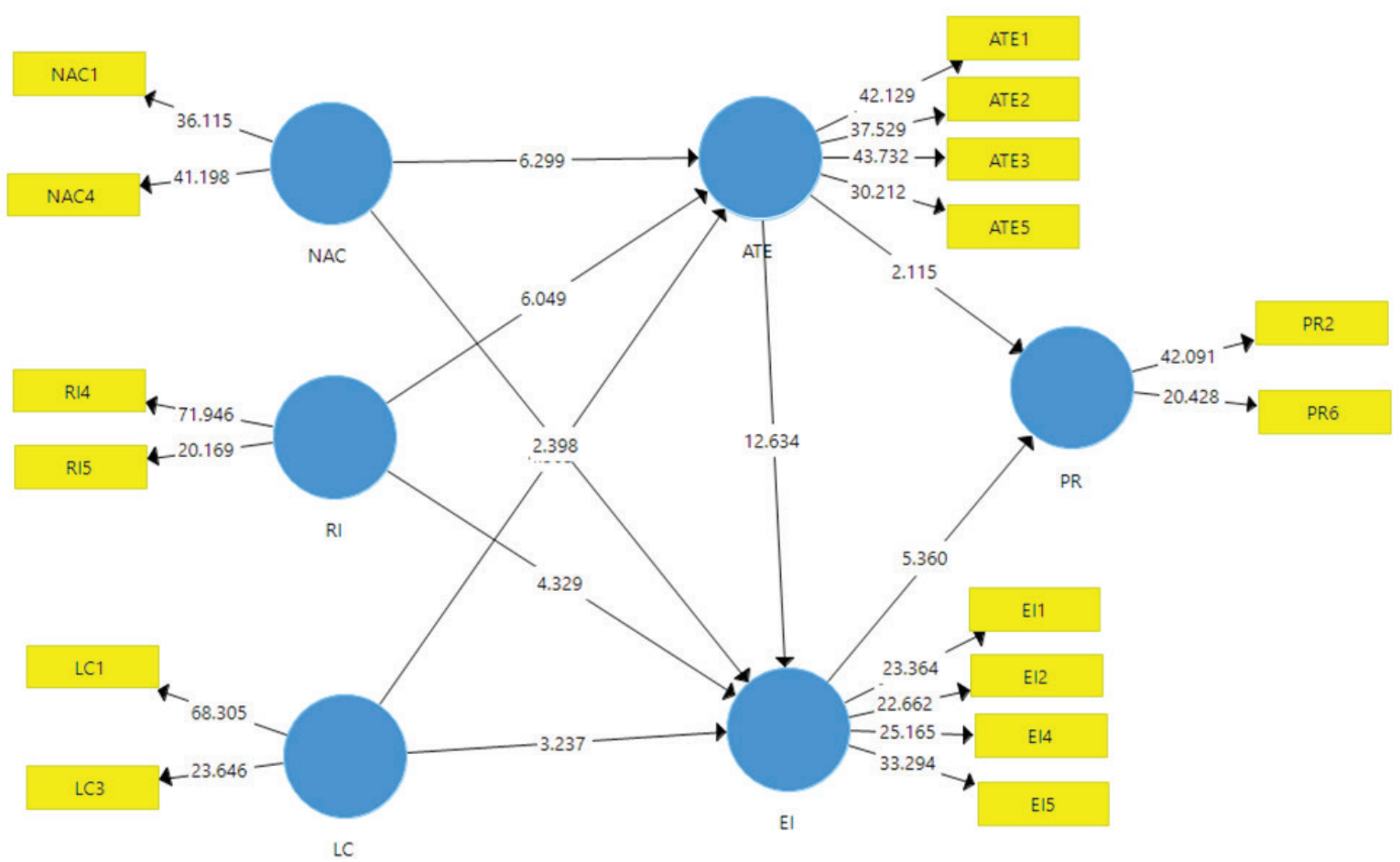

Figure 2: Measurement and structural model estimation

and LC, which is a moderate level of predictivity. Lastly, 0.302 or $30.2 \%$ variance of PR was explained by ATE, NAC, RI, LC and EI, which is as weak level of predictivity. In addition to evaluating the $\mathrm{R}^{2}$ value, the $\mathrm{f}^{2}$ effect size test was employed. The assessment of the effect size $\mathrm{f}^{2}$ seeks to evaluate whether exogenous constructs have a substantive impact on endogenous constructs. Based on the guidelines provided by Hair et al. (2014), $\mathrm{f}^{2}$ values of $0.02,0.15$, and 0.35 respectively represent the small, medium, and large effect of the exogenous constructs on the endogenous constructs. The range of $f^{2}$ is between $0.014-0.149$. Specifically, the effect size of NAC, $\mathrm{LC}$ and $\mathrm{RI}$ on ATE were moderate ( $\mathrm{f}^{2}$ values are 0.149 and 0.104). Similarly, the effect size of NAC, LC, RI and ATE o on EI were substantial ( $\mathrm{f}^{2}$ values is 0.474). However, the effect size of ATE and EI on PR were weak level ( $\mathrm{f}^{2}$ values are 0.014 and 0.093 ).

\section{Discussion}

The results of this study answer nine hypotheses (see Table 3 and Figure 2). The first and second hypotheses confirmed that there is a direct positive impact between the 
need for achievement toward entrepreneurial attitude and entrepreneurial intentions. The results of the study support several previous studies by Botsaris and Vamvaka (2016); Dakoumi and Abdelwahed (2014); Jena (2020), which indicate that the need for achievement significantly influences attitudes toward entrepreneurship and entrepreneurial intentions. The young entrepreneurs think that they can make much money by doing things that are considered productive. They also need to set short- and long-term goals and strategies to grow the business (Greco \& Kraimer, 2020). Using information channels from various media, both online and offline, they seek knowledge in doing business. This young entrepreneur has the spirit of entrepreneurship and never gives up in any situation.

Entrepreneurs must be more concerned about doing their job well than others. This shows that they intend to become superior people. An entrepreneur must have analytical skills, especially to analyze the business. By analyzing the business, both in terms of competitors and developing the business. Also, when analyzing a business, entrepreneurs must be able to think long term. This is because they can use the results of the analysis to develop the business going forward. If entrepreneurs do not think long term, then they do not expect their business to be long lasting (Lévesque \& Stephan, 2019).

The next findings are that risk perception positively influences attitudes toward entrepreneurial intentions. This study supports some prior studies by Padilla-Meléndez et al. (2014); Vinothkumar and Subramanian (2016). The young entrepreneurs see that a good relationship is needed to start a business. There is a need for good social skills in establishing business partnerships, and they need to understand the characteristics of their colleagues (Gold \& Heinemann, 2019). Choosing the right business partner or partners is crucial in starting a business partnership (Gretsch et al., 2020; Leminen et al., 2019). If young entrepreneurs make the wrong choice, this can affect their relationship with their business partners. Young entrepreneurs also need to have an understanding of the law to start a business. With the regulation of business law, it is expected to reduce the potential risks that can occur, especially for small- and medium-sized entrepreneurs who generally lack knowledge and access to legal information (Heuer \& Seuring, 2020).

This study also confirms that the locus of control can explain young people attitudes toward entrepreneurship and the intention to be entrepreneurs. This study confirms prior works conducted by Rajh et al. (2017); Laspita et al. (2012), Liñán et al. (2011); Stevenson and Jarillo (2007). Respondents believe that their business' future sustainability is determined by their own actions (Hsu et al., 2016; Tarling et al., 2016). Many companies in Indonesia are competing to become superior companies. As a consequence, the companies should fight hard to maintain their competitive edge (Firman et al., 2020). Globalization causes the number of competitors in business to increase, and most of the increasing number of competitors is from abroad. Sustainable growth is the primary goal of every company. Business growth is also inseparable from family business planning and the phenomenon of sustainability (Tien, 2019).

Young entrepreneurs' success or not in business, to a large extent, dependents on their own abilities (Bammer et al., 2020). The ability to do business is faced with freedom in determining their life goals. Freedom in running one's own business, and achieving one's own life goals makes many people choose to become superior entrepreneurs (Mazzarol $\&$ Reboud, 2020). Some entrepreneurs use their freedom to arrange their personal life and work behavior flexibly. They can determine their own business achievement target, freedom in using resources, and not dependent on others (Minkov et al., 2019). The business activities they are involved in are tools to optimize their potential and selfactualization statements. Entrepreneurs realize that the limits to their success are all things that are determined by their own creativity, enthusiasm, and vision.

The study results showed that there is a correlation between entrepreneurial attitude, entrepreneurial intention, and preparing for entrepreneurship. These findings are in line with the results of research conducted by Jena (2020), Liñán et al. (2011), and Borasi and Finnigan (2010). These young entrepreneurs consider that an entrepreneurial career becomes an exciting profession for them (Zhao et al., 2020). Being a successful entrepreneur is everyone's dream, but to achieve that is not easy. Many obstacles always come in turns. If an entrepreneur is able to face every problem with a steady hand, he will undoubtedly become a successful and independent entrepreneur. Every entrepreneur handling every problem requires excellent individual skills (Funken et al., 2018; Singh \& Majumdar, 2020; Saptono et al., 2018). This skill is generally gained from education or may be based on an entrepreneur's experience during their career.

The profession of entrepreneurs makes young people more satisfied with the extraordinary achievement of their life goals. By choosing to be an entrepreneur means that they are free from all the tedious rules of work, for example, wearing work uniforms, being in boring room designs, age restrictions, and limited time for yourself. Through freedom, while working, they are guaranteed to be happier in life (Stein, 2019). If there are opportunities and resources, these young entrepreneurs will make the best use to start entrepreneurship. Market characteristics are essential to be recognized further when conducting business opportunity analysis (Sinyard et al., 2018). Targets like what young entrepreneurs are aiming for and whether they are interested in the products that will be offered. 
The last hypothesis showed that a significant influence between entrepreneurial intention and preparing for entrepreneurship. In preparing for business activities, young entrepreneurs are ready to do anything to become an entrepreneur; a great motivation is needed here both instinctively and extrinsically (Borasi \& Finnigan, 2010; Boissin et al., 2006; Mahendra et al., 2017), by preparing themselves to increase their competence in business (Baion \& Marfcman, 2000; Liñán, 2008). Competence is a characteristic of someone who has the skills, knowledge, and ability to conduct business (Padilla-Meléndez et al., 2014). The need for business education and training is a provision in business preparation. They will try as much as possible to start and run their own business.

Young entrepreneurs have a great determination to create business ventures in the future (Davis, 2013). Deciding to become an entrepreneur means that they decide to have enough determination, perseverance, and capital to get started. The most important capital to become a successful entrepreneur is to never give up and keep trying, although it must be admitted that many surrenders before attaining success. Successful entrepreneurs do not make problems significant obstacles, instead they see opportunities (Mcmullen \& Kier, 2016). A true entrepreneur is always positive and open-minded to continue to create and innovate in order to achieve his goals (Schaefer \& Minello, 2019).

The professional goal in their lives is to become a successful entrepreneur (Ang \& Hong 2000). To be a successful person, young entrepreneurs need perseverance and strong mentality, need for achievement, risk perception, locus of control, attitudes towards entrepreneurship, and entrepreneurial intentions (Barbosa \& Fayolle, 2006; Linden, 2017). Usually, people who are at the peak of success have different patterns and ways of thinking compared to new people who will achieve success (Cui et al., 2019; Mcmullen \& Kier, 2016). Everyone must have a dream and a life plan they have set (Dejaeghere, 2014; Greco \& Kraimer, 2020). However, the difference is, successful entrepreneurs not only have dreams, but they also do various things to achieve the goals they have set. They will write a step-by-step plan to achieve these goals (Nabi \& Liñán, 2013). Indeed, Ferreira et al. (2012) and Nasip et al. (2017) also confirmed that the need for achievement is positively related to entrepreneurial intentions. This study also supports numerous works conducted (Borasi \& Finnigan, 2010; Nowiński \& Haddoud, 2019).

\section{Conclusions}

This study aimed to investigate the determinant factors affecting young people in preparing for entrepreneurship. The findings showed that the entrepreneurial attitude and entrepreneurial intention can be explained by the need for achievement, risk taking, and locus of control. This study confirms a robust correlation between entrepreneurial attitude, entrepreneurial intention, and preparation for entrepreneurship. This study suggests that, first, the government institutions and universities need to be concerned about entrepreneurial programs to promote young entrepreneurs. Second, in starting a business, it is necessary to involve several stage holders in supporting their business activities, faced by young entrepreneurs. Third, young entrepreneurs still have the locus of control that needs to be increased. They need a more global mindset that makes them able to survive to run their business well. In this condition, the need for high motivation for these entrepreneurs to be able to work hard independently. Fourth, the formation of the attitude of young entrepreneurs who are very supportive of business activities is essential. In this case, entrepreneurs can make an appropriate and future-oriented analysis and have a high creative power. The need to participate in some business communities, both with beginners and those who have succeeded, will have an impact on the formation of young entrepreneurs' character. Further research should include, not only young entrepreneurs, but also students in vocational schools or vocational education. Further studies need to consider other variables such as perceived behavioral control, start-up business motivation or institutional environment, which are missing in this study.

\section{References}

Ajzen, I. (1987). Attitudes, Traits and Actions: Dispositional Prediction of Behavior in Personality And. Advances in Experimental Social Psychology, 20, 1-63.

Ajzen, I. (2002). Perceived behavioral control, self-efficacy, locus of control, and the theory of planned behavior. Journal of Applied Social Psychology, 32(4), 665-683. https://doi. org/10.1111/j.1559-1816.2002.tb00236.x

Ajzen, I., \& Fishbein, M. (1997). Understanding Attitudes and Predicting Social Behavior. Englewood Cliffs, NJ: Prentice Hall.

Ang, S. H., \& Hong, D. G. (2000). Entrepreneurial spirit among east Asian Chinese. Thunderbird International Business Review, 42(3), 285-309.

Baion, R. A., \& Marfcman, G. D. (2000). Beyond social capital: How social skills can enhance entrepreneurs' success. Academy of Management Perspectives, 14(1), 106-116.

Bammer, G., O'Rourke, M., O'Connell, D., Neuhauser, L., Midgley, G., Klein, J. T., ... \& Fulton, E. A. (2020). Expertise in research integration and implementation for tackling complex problems: when is it needed, where can it be found and how can it be strengthened? Palgrave Communications, 6(1), 1-16. https://doi.org/10.1057/s41599-019-0380-0

Barbosa, S. D., \& Fayolle, A. (2006). Assessing risk perception, self-efficacy, and entrepreneurial attitudes and intentions: 
Implications for entrepreneurship education. HAL. https:// econpapers.repec.org/RePEc:hal:journl:halshs-00135101

Bonnett, C. (1991). Who wants to be an entrepreneur? A study of adolescents interested in a Young Enterprise scheme. Journal of Economic Psychology, 12, 465-478.

Borasi, R., \& Finnigan, K. (2010). Entrepreneurial Attitudes and Behaviors that Can Help Prepare Successful Change-Agents in Education Entrepreneurial Attitudes and Behaviors That Can Help Prepare Successful. The New Educator, 6(1), 1-29. https:// doi.org/10.1080/1547688X.2010.10399586

Botsaris, C., \& Vamvaka, V. (2016). Attitude toward Entrepreneurship: Structure, Prediction from Behavioral Beliefs, and Relation to Entrepreneurial Intention. Journal of the Knowledge Economy, 7(2), 433-460. https://doi. org/10.1007/s13132-014-0227-2

Chant, S., \& Jones, G. A. (2005). Youth, Gender and Livelihoods in West Africa: Perspectives from Ghana and the Gambia. Children's Geographies, 3(2), 185-199. https://doi. org/10.1080/14733280500161602

Connor, A. O. (2013). Journal of Business Venturing A conceptual framework for entrepreneurship education policy: Meeting government and economic purposes. Journal of Business Venturing, 28(4), 546-563. https://doi.org/10.1016/j. jbusvent.2012.07.003

Cromie, S., \& O’Donaghue, J. (2000). Assessing entrepreneurial inclinations. International Small Business Journal, 10(2), 66-73. https://doi.org/10.1080/135943200398030

Cronbach, L. J. (1995). Giving method variance its due. In: P. E. Shrout \& S. T. Fiske (Eds.), Personality research, methods, and theory: A festschrift honoring Donald W. Fiske (pp. 145-157). Mahwah, NJ: Lawrence Erlbaum Associates, Inc.

Dakoumi, H. A., \& Abdelwahed, Y. (2014). Is Entrepreneurship for You? Effects of Storytelling on Entrepreneurial Intention. International Journal of Business and Management, 9(9), 176-192. https://doi.org/10.5539/ijbm.v9n9p176

Davis, M. K. (2013). Entrepreneurship: an Islamic perspective. International Journal of Entrepreneurship and Small Business, 20(1), 63-69.

Dejaeghere, J. (2014). Entrepreneurship education for youth in sub-Saharan Africa: A capabilities approach as an alternative framework to neoliberalism's individualizing risks. Progress in Development Studies, 14(1), 61-76. https://doi. org/10.1177/1464993413504353

Douglas, E. (2017). Perceptions: Looking at the World through Entrepreneurial Lenses. In: Revisiting the Entrepreneurial Mind, Cham. Switzerland: Springer International Publishing. DOI: $10.1007 / 978-3-319-45544-0 \_4$

Fazio, R. H., \& Williams, C. J. (2015). Attitude Accessibility as a Moderator of the Attitude-Perception and Attitude-Behavior Relations. An Investigation of the 1984 Presidential Election. Journal of Personality and Social Psychology, 51(3), 505. https://doi.org/10.1037/0022-3514.51.3.505
Ferreira, J. J., Raposo, M. L., Rodrigues, R. G., Dinis, A., \& Paço, A. D. (2012). A model of entrepreneurial intention: an application of the psychological and behavioral approaches. Journal of Small Business and Enterprise Development, 19(3), 424-440. https://doi.org/10.1108/14626001211250144

Filion, L. J. (2015). Entrepreurship and Management: Differing but Complementary Processes. École Des Hautes Études Commerciales, Chaire d'entrepreneurship Maclean Hunter., February 1995.

Firman, A., Mustapa, Z., \& Ilyas, G. B. (2020). Relationship of TQM on Managerial Performance: Evidence from Property Sector in Indonesia. Journal of Distribution Science, 18(1), 47-57. https://doi.org/10.15722/jds.17.12.20201.47

Fitch, A. J., Kadyrov, A., Christmas, W. J., \& Kittler, J. (2005). Fast robust correlation. IEEE Transactions on Image Processing, 14(8), 1063-1073.

Fock, S. T., \& Koh, H. C. (2006). Conceptualization of Trust, Commitment, and Understanding the Relationships between Trust, Commitment, and Willingness to Try Internet Banking Services. International Journal of Business and Information, 1(2), 194-208. Research Collection Lee Kong Chian School of Business. Available at: https://ink.library.smu.edu.sg/lkcsb_ research/3796

Fornell, C., \& Larcker, D. F. (1981). Structural equation models with unobservable variables and measurement error: Algebra and statistics. Journal of Marketing Research, 18(3), 382-388. https://doi.org/10.1177/002224378101800313

Fox, S., \& Spector, P. E. (1999). A model of work frustrationaggression. Journal of Organizational Behavior, 20(6), 915-931. https://doi.org/10.1002/(SICI)1099-1379

Funken, R., Gielnik, M. M., \& Foo, M. (2018). How Can Problems Be Turned Into Something Good? The Role of Entrepreneurial Learning and Error Mastery Orientation. Entrepreneurship Theory and Practice, 44(2), 1-24. https://doi. org/10.1177/1042258718801600

Gold, S., \& Heinemann, K. (2019). Social business collaboration at the bottom of the pyramid: The case of orchestration. Business Strategy and the Environment, 29(1), 262-275. https://doi. org/10.1002/bse. 2363

Gomez-Mejia, L. R., \& Balkin, D. B. (1989). Effectiveness of individual and aggregate compensation strategies. Industrial Relations: A Journal of Economy and Society, 28(3), 431-445.

Greco, L. M., \& Kraimer, M. L. (2020). Goal-Setting in the Career Management Process: An Identity Theory Perspective. Journal of Applied Psychology, 105(1), 40-57. https://doi.org/10.1037/ ap10000424

Gretsch, O., Tietze, F., \& Kock, A. (2020). Firms' intellectual property ownership aggressiveness in university - industry collaboration projects: Choosing the right governance mode. Creativity and Innovation Management, 29(2), 1-12. https:// doi.org/10.1111/caim.12354 
Hair Jr, J. F., Sarstedt, M., Hopkins, L., \& Kuppelwieser, V. G. (2014). Partial least squares structural equation modeling (PLSSEM). European Business Review, 26(2), 106-121. https://doi. org/10.1108/EBR-10-2013-0128

Hair, J. F., Ringle, C. M., \& Sarstedt, M. (2013). Partial least squares structural equation modeling: Rigorous applications, better results and higher acceptance. Long Range Planning, 46(1-2), $1-12$.

Helson, R. (1980). Personality_Theory, assessment, and research. Psyccritiques, 25(10). https://doi.org/10.1037/019334.

Heuer, M. A., \& Seuring, S. (2020). Bottoms up: Delivering sustainable value in the base of the pyramid. Business Strategy and the Environment, 29(3), 1605-1616. https://doi. org/10.1002/bse. 2465

Hill, M. (2006). Children's voices on ways of having a voice: Children's and young people's perspectives on methods used in research and consultation. Childhood, 13(1), 69-89. https://doi. org/10.1177/0907568206059972

Hsiao, C., Lee, Y., \& Chen, H. (2015). The International Journal of Human the effects of internal locus of control on entrepreneurship: the mediating mechanisms of social capital and human capital. The International Journal of Human Resource Management, 27(11), 1158-1172. https://doi.org/10. $1080 / 09585192.2015 .1060511$

Hsu, D. K., Wiklund, J., Anderson, S. E., \& Coffey, B. S. (2016). Entrepreneurial exit intentions and the business-family interface. Journal of Business Venturing, 31(6), 613-627. https://doi.org/10.1016/j.jbusvent.2016.08.001

Hunter, A. S., Kapp, J., \& Yonkers, V. (2003). A psychological model of entrepreneurial behaviour. Journal of the Academy Business and Economics, 2(2), 180-192.

Iakovleva, T., \& Kolvereid, L. (2011). Entrepreneurial intentions in developing and developed countries. Education + Training, 53(5), 353-370. https://doi.org/10.1108/00400911111147686

Jena, R. K. (2020). Measuring the impact of business management Student's attitude towards entrepreneurship education on entrepreneurial intention: A case study. Computers in Human Behavior, 107. 106275. https://doi.org/10.1016/j. chb.2020.106275

Laspita, S., Breugst, N., Heblich, S., \& Patzelt, H. (2012). Intergenerational transmission of entrepreneurial intentions. Journal of Business Venturing, 27(4), 414-435. https://doi. org/10.1016/j.jbusvent.2011.11.006

Leminen, S., Rajahonka, M., Wendelin, R., \& Westerlund, M. (2019). Industrial internet of things business models in the machineto-machine context. Industrial Marketing Management, 84, 298-311. https://doi.org/10.1016/j.indmarman.2019.08.008

Lévesque, M., \& Stephan, U. (2019). It's Time We Talk about Time in Entrepreneurship. Entrepreneurship Theory and Practice, 44(2), 1-22. https://doi.org/10.1177/1042258719839711

Liñán, F., \& Chen, Y. W. (2009). Development and cross-cultural application of a specific instrument to measure entrepreneurial intentions. Entrepreneurship Theory and Practice, 33(3), 593-617.

Linan, F., Rodríguez-Cohard, J. C., \& Rueda-Cantuche, J. M. (2011). Factors affecting entrepreneurial intention levels: A role for education. International Entrepreneurship and Management Journal, 7(2), 195-218. https://doi.org/10.1007/ s11365-010-0154-Z

Lordkipanidze, M., Brezet, H., \& Backman, M. (2005). The entrepreneurship factor in sustainable tourism development. Journal of Cleaner Production, 13, 787-798. https://doi. org/10.1016/j.jclepro.2004.02.043

Luc, P. T. (2018). The relationship between perceived access to finance and social entrepreneurship intentions among university students in Vietnam. Journal of Asian Finance, Economics and Business, 5(1), 63-72. http://dx.doi.org/10.13106/jafeb.2018. vol5.no1.63

Ma, H., \& Tan, J. (2006). Key components and implications of entrepreneurship: A 4-P framework. Journal of Business Venturing, 21(5), 704-725. https://doi.org/10.1016/j. jbusvent.2005.04.009

Markman, G. D., \& Baron, R. A. (2003). Person - entrepreneurship fit: why some people are more successful as entrepreneurs than others. Human Resource Management Review, 13, 281-301. https://doi.org/10.1016/S1053-4822(03)00018-4

Mazzarol, T., \& Reboud, S. (2020). Work Book: Entrepreneurs vs. Owner-Managers. In: Workbook for Small Business Management. Singapore: Springer.

McClelland, D. C. (1961). The achieving society. Princeton, NJ: Van Nostrand. Available at: https://www.worldcat.org/title/ achieving-society/oclc/230046

McGee, J. E., Peterson, M., Mueller, S. L., \& Sequeira, J. M. (2009). Entrepreneurial self-efficacy_refining the measure. Entrepreneurship Theory and Practice, 33(4), 965-988. https:// doi.org/: 10.1111/j.1540-6520.2009.00304.x

McMullen, J. S., \& Kier, A. S. (2016). Trapped by the entrepreneurial mindset: Opportunity seeking and escalation of commitment in the Mount Everest disaster. Journal of Business Venturing, 31(6), 663-686.

Minkov, M., Welzel, C., \& Schachner, M. (2019). Cultural Evolution Shifts the Source of Happiness from Religion to Subjective Freedom. Journal of Happiness Studies, 0123456789. https:// doi.org/10.1007/s10902-019-00203-w

Mueller, S. L., \& Thomas, A. S. (2001). Culture and entrepreneurial potential: A nine country study of locus of control and innovativeness. Journal of Business Venturing, 16(1), 51-75. https://doi.org/10.1016/S0883-9026(99)00039-7

Nabi, G., \& Liñán, F. (2013). Considering business start-up in recession time: The role of risk perception and economic. International Journal of Entrepreneurial Behavior \& Research, 19(6), 633-655. https://doi.org/10.1108/IJEBR-10-2012-0107

Nasip, S., Amirul, S. R., Sondoh Jr, S. L., \& Tanakinjal, G. H. (2017). Psychological characteristics and entrepreneurial intention A study among university students in North Borneo, 
Malaysia. Education+ Training, 59(7), 825-840. https://doi. org/10.1108/ET-10-2015-0092

Nelles, J. (2011). Entrepreneurial Architecture: A Blueprint for Entrepreneurial Universities. Canadian Journal of Administrative Sciences, 353, 341-353.

Nga, J. K. H., \& Shamuganathan, G. (2010). The Influence of Personality Traits and Demographic Factors on Social Entrepreneurship Start Up Intentions. Journal of Business Ethics, 95(2), 259-282. https://doi.org/10.1007/s10551-0090358-8

Nowiński, W., \& Haddoud, M. Y. (2019). The role of inspiring role models in enhancing entrepreneurial intention. Journal of Business Research, 96, 183-193. https://doi.org/10.1016/j. jbusres.2018.11.005

Padilla-Meléndez, A., Fernández-Gámez, M. A., \& MolinaGómez, J. (2014). Feeling the risks: effects of the development of emotional competences with outdoor training on the entrepreneurial intent of university students. International Entrepreneurship and Management Journal, 10(4), 861-884.

Priem, R. L., \& Carr, J. C. (2012). Insights and New Directions from Demand-Side Approaches to Technology Innovation, Entrepreneurship, and Strategic Management Research. Journal of Management, 38(1), 346-374. https://doi. org/10.1177/0149206311429614

Rajh, E., Budak, J., Ateljević, J., Davčev, L., Jovanov, T., \& Ognjenović, K. (2017). Entrepreneurial intentions in selected South-East European countries. Glasnik Srpskog Geografskog Društva, 592-610.

Rode, V., \& Vallaster, C. (2005). Corporate Branding for Startups: The Crucial Role of Entrepreneurs. Corporate Reputation Review, 8(2), 121-135. https://doi.org/10.1057/palgrave. crr. 1540244

Rotter, J. B. (1966). Generalized expectancies for internal versus external control of reinforcement. Psychological Monographs: General and Applied, 80(1). https://doi.org/10.1037/h0092976.

Saptono, A \& Wibowo, A. (2018). Do Learning Environment and Self-Efficacy Impact on Students Entrepreneurial Attitude? International Journal of Entrepreneurship, 22(4), 1-12.

Schaper, M., \& Weber, P. (2011). Entrepreneurship and Small Business (3nd ed.). Milton, Australia: John Wiley and Sons.

Schifter, D. E., \& Ajzen, I. (1985). Intention, perceived control, and weight loss: an application of the theory of planned behavior. Journal of Personality and Social Psychology, 49(3), 843-851. doi: 10.1037//0022-3514.49.3.843.

Schwartz, D., \& Malach-Pines, A. (2009). Entrepreneurship Education for Students: How Should Universities Prepare for the Challenge of Teaching Entrepreneurship? Industry and Higher Education, 23(3), 221-231. https://doi. org/10.5367/000000009788640305

Simon, M., Houghton, S. M., \& Aquino, K. (2000). Cognitive biases, risk perception, and venture formation: How individuals decide to start companies. Journal of Business Venturing, 15(2), 113-134.
Singh, A., \& Majumdar, S. (2020). Entrepreneurship: Nation as a Context. In: Majumdar S., Reji E. (eds.), Methodological Issues in Social Entrepreneurship Knowledge and Practice. Springer Proceedings in Business and Economics. Springer, Singapore. https://doi.org/10.1007/978-981-13-9769-1_11

Sinyard, D. B., Dionne, S. S., \& Loch, K. D. (2018). Fast Thinking in Private Equity: The Role of Heuristics in Screening Buyout Opportunities. Journal of Small Business Management, 1-28. [Online First]. https://doi.org/10.1111/jsbm.12451

Stein, S. (2019). Hegel and Aristotle on Ethical Life: Duty- Bound Happiness and Determined Freedom. Hegel Bulletin, 41(1), 61-82. https://doi.org/10.1017/hgl.2019.22

Stevenson, H. H., \& Jarillo, J. C. (2007). A paradigm of entrepreneurship: Entrepreneurial management. Entrepreneurship: Concepts, Theory and Perspective, 11, 155-170. https://doi.org/10.1007/978-3-540-48543-8_7

Suparno., Wibowo, A., Mukhtar, S., Narmaditya, B. S., \& Sinta, H. D. (2019). The Determinant Factors of Development Batik Cluster Business: Lesson from Pekalongan, Indonesia. Journal of Asian Finance, Economics and Business 6(4), 227-233. https://doi.org/10.13106/jafeb.2019.vol6.no4.227

Tang, T. L. (1995). The development of a short money ethic scale: Attitudes toward money and pay satisfaction revisited. Personality and Individual Differences, 19(6), 809-816. https:// doi.org/10.1016/S0191-8869(95)00133-6

Tarling, C., Jones, P. and Murphy, L. (2016). Influence of early exposure to family business experience on developing entrepreneurs. Education + Training, 58(7/8), 733-750. https:// doi.org/10.1108/ET-03-2016-0050

Tien, N. H. (2019). Corporate financial performance due to sustainable development in Vietnam. Corporate Social Responsibility and Environmental Management, 27(2), 1-12. https://doi.org/10.1002/csr.1836

Tong, X. F., Tong, D. Y. K., \& Loy, L. C. (2011). Factors influencing entrepreneurial intention among university students. International Journal of Social Sciences and Humanity Studies, 3(1), 487-496.

Vinothkumar, M., \& Subramanian, S. (2016). Self-Efficacy, Attitude and Subjective Norms as Predictors of Youth's Intention to Enlist in Defence Services. Journal of the Indian Academy of Applied Psychology, 42(2), 193. DOI: 10.1037/t59415-000

Wagner, J., \& Sternberg, R. (2004). Start-up activities, individual characteristics, and the regional milieu: Lessons for entrepreneurship support policies from German micro data. The Annals of Regional Science, 38, 219-240. https://doi. org/10.1007/s00168-004-0193-x

Yi, H. T., Han, C. N., \& Cha, Y. B. (2018). The Effect of Entrepreneurship of SMEs on Corporate Capabilities, Dynamic Capability and Technical Performances in South Korea. Journal of Asian Finance, Economics and Business, 5(4), 135-147. http://doi.org/10.13106/jafeb.2018.vol5.no4.135 